\title{
The Structural Injustice of Forced Migration and the Failings of Normative Theory
}

David Ingram

Loyola University Chicago, dingram@luc.edu

Follow this and additional works at: https://ecommons.luc.edu/philosophy_facpubs

Part of the Ethics and Political Philosophy Commons, Inequality and Stratification Commons, Legal Theory Commons, Political Economy Commons, and the Political Theory Commons Author Manuscript

This is a pre-publication author manuscript of the final, published article.

\section{Recommended Citation}

Ingram, D. "The Structural Injustice of Forced Migration and the Failings of Normative Theory." Perspectives on Global Development and Technology, 11(4) 2012: 50-71.

This Article is brought to you for free and open access by the Faculty Publications and Other Works by Department at Loyola eCommons. It has been accepted for inclusion in Philosophy: Faculty Publications and Other Works by an authorized administrator of Loyola eCommons. For more information, please contact ecommons@luc.edu. cc) (i) $\Theta$

This work is licensed under a Creative Commons Attribution-Noncommercial-No Derivative Works 3.0 License. (C) 2012 Brill 
The Structural Injustice of Forced Migration and the Failings of Normative Theory

David Ingram

\section{Loyola University Chicago}

Keywords: immigration, capitalism, liberalism, communitarianism, discourse ethics

Abstract: I propose to criticize two strands of argument - contractarian and utilitarian - that liberals have put forth in defense of economic coercion, based on the notion of justifiable paternalism. To illustrate my argument, I appeal to the example of forced labor migration, driven by the exigencies of market forces. In particular, I argue that the forced migration of a special subset of unemployed workers lacking other means of subsistence (economic refugees) cannot be redeemed paternalistically as freedom or welfare enhancing in the long run. I further argue that contractarian and utilitarian approaches are normatively incapable of appreciating this fact because the kinds of reasons that they adduce for justifying the long-term freedom-enhancing consequences of forced migration are not ones that would be acceptable to the migrants themselves. I conclude that only a discourse ethical approach, which mandates direct, empathetic communication between would-be migrants and members of potential host communities, captures the full range of reasons that would be acceptable to both migrants and members of these communities. These reasons - appealing both to agency-enhancing communal attachments as well as to agency-enhancing freedom of choice - fully reveals the extent to which a global capitalist system composed of relatively closed national communities coerces the world's poorest migrants. 
Marxists have long criticized capitalism as a coercive system. However, aside from noting how the coercive nature of capitalism belies its alleged reputation as a system built on voluntary exchange, they have not shown why economic coercion is any different from other forms of coercion (legal or paternalistic) that may be justified. In order to show why capitalist economic coercion is wrong we need to move beyond Marxist ideology critique to normative theory in the liberal tradition. Liberals defend legal coercion as mutually beneficial, universally freedom enhancing, and therefore as generally agreeable to all. They defend paternalistic coercion, which by definition is not agreeable to those coerced, on the grounds that it also enhances the latter's freedom or welfare, albeit "in the long run," and in a manner agreeable to them "counterfactually," from a post facto perspective. I submit that apologists of capitalism must appeal to either of the above rationales in justifying the coercive impact of capitalist markets in directly or indirectly compelling people to make choices that they view as contrary to their interests.

In this paper I propose to examine these rationales in greater detail. While some liberals do argue that any decision made in response to market forces is as voluntary as any decision made in response to legal forces, thereby relieving the economic system of its coercive or non-consensual nature, this argument, as Marxists have shown, is implausible when addressing the weakest and most vulnerable parties to contractual exchange, who do not acknowledge the market as mutually beneficial and who have no other economic choice than the one offered to them by the owner of capital. The question then arises whether even the weaker party's option-less choice, which is viewed by them as a coerced choice to "work or starve," can be justified on paternalistic grounds.

The argument of this paper is that it cannot. I propose to criticize two strands of argument - contractarian and utilitarian - that liberals have put forth in defense of economic coercion, based on the notion of justifiable paternalism. To illustrate my argument, I appeal to the example of forced labor migration involving economic refugees, who have lost their jobs due to global market dislocations, thereby depriving them of their sole means of subsistence. I argue that this kind of forced migration is no more justifiable on paternalistic grounds than the forced migration of political refugees caused by political oppression, since both involve life-threatening violations (or threatened violations) of basic human rights. The fact that such forced migrations might be freedom (or agency) enhancing in the long run is disputable and irrelevant to the question of redeeming the kind of coercion that is implicated. I further argue that contractarian and utilitarian approaches are normatively incapable of appreciating this fact because the kinds of reasons they adduce for justifying the long-term freedomenhancing consequences of forced migration are not ones that would be acceptable to the migrants themselves. This is because reasons that merely refer to a greater opportunity to maximize or enhance overall utility and/or freedom of choice exclude the most important agency-specific quality of life variables, namely, those concerning the cultivation and maintenance of intact relationships of community and communicative empowerment. Communitarian approaches, which are generally more critical of the destabilizing and coercive effects of capitalism than their liberal counterparts, better capture the sorts of reasons that matter to would-be migrants. However, because they privilege community 
over freedom of choice, they neglect one type of legitimate reason that would-be migrants might adduce for migrating from one community to another.

I conclude that only a discourse ethical approach, which mandates direct, empathetic communication between would-be migrants and members of potential host communities, captures the full range of reasons that would be acceptable to both migrants and members of these communities. These reasons, which appeal both to agencyenhancing communal attachments as well as to agency-enhancing freedom of choice, reveal the full extent to which a global capitalist system composed of relatively closed national communities coerces the world's poorest migrants.

Coercion and Migration: Preliminary Remarks

Coercive are situations in which people are forced to do something they would not do, were it not for the sake of avoiding some harm (trivial or grave) that ordinary persons or officials of the state threaten to visit upon them. People coerce others in order to benefit themselves, as when a mugger threatens to beat a passerby unless she hands over her purse. Often times, they do so for the benefit of the one being coerced, as when parents threaten to hand their children over to the police unless they stop using illicit drugs. Occasionally, the motive for coercion combines self-interest with altruism.

Self-interest combined with altruism might well explain our widespread indifference to another kind of coercion: the forced migration of the desperately poor. The supposition that much of today's migration is coerced appears plausible if we assume that many people today migrate in order to avoid the misery of poverty caused in part by economic structures that have been imposed upon them against their will. The supposition that such structures work to the long-term benefits of all persons, including migrants, might then explain our willingness to acquiesce in permitting this coercion on paternalistic grounds.

In this paper I will argue this justification succeeds only if the migrants in question would freely consent to their coercion as advancing either their freedom to choose without restraint and from a wide spectrum of options or their capacity to act as fully autonomous agents in light of less coercive economic alternatives. My argument against such a justification begins by discussing what I take to be paradigm cases of coercion and examines the reasons for paternalistic coercion that enhances the long-term freedom of those who are coerced. I then recount widely accepted arguments why impersonal structures besides government sanctions and including economic forces - no less than personal actions - can be described as coercive (consciously permitted) and not merely as naturally compelled in a way that is beyond human control. All the world's inhabitants contribute in some way to maintaining economic structures that coerce economic refugees into abandoning their families and communities for the sake of procuring better employment abroad.. But some share greater responsibility in this regard than others, so that describing these structures as impersonal in no way absolves us of our prima facie duty to make these structures less coercive. The question then arises whether this duty can be overridden by arguing that the coercion in question is justified on paternalistic grounds, as enhancing the freedom of migrant workers in the long run. Answering in the negative, I argue that neither liberal nor communitarian approaches to this question capture the freedom- (agency- or welfare-) denying effects of immigration from the perspective of the (would-be) migrant. In order to capture the truly coercive (and 
non-paternalistic) nature of the economically motivated migration undertaken by economic refugees, I appeal to discourse ethics, which holds that a coercive structure is legitimate if and only if all affected by it could rationally consent to it from the standpoint of their own historical situation - a consent that at least many desperate migrants would likely withhold if they were asked to decide the legitimacy of the current global economic order. ${ }^{1}$

\section{Justifying Coercion}

When we think of coercion we typically imagine a case where person A forces person B to do something that B doesn't want to do in order to advance A's interest. On the face of it, such coercion exemplifies an injustice. Yet further reflection shows that this need not be the case. A's law that coerces would-be criminal B into being a good citizen advances both A's and B's interests justly. Indeed, even if the law did not advance B's interest, we would still say that it was justified for the sake of protecting A from B's criminal aggression. However, when the coercion in question does not aim at preventing a serious harm to others its justification seems less evident. In this latter instance coercion is defensible if it can be shown to advance an important interest of the one being coerced, as when a parent forces her child to eat the nourishing vegetables on her plate. Still, as John Stuart Mill forcefully argued in On Liberty (1859), what is defensible in the case of children may not be defensible in the case of adults, to whom we owe special consideration on account of their capacity to make rational and informed decisions. According to Mill, countermanding the will of person B on the ground that one knows better than B what is in B's best interest is a sign of supreme arrogance even when the presumption of superior insight is justified. For the good occasioned by forcing B to do what is in his best interest is typically nullified by the evil caused by denying his freedom. That said, Mill had no objection to compelling persons to act contrary to preferences that undermine their own agency, as when persons contract to sell themselves into bondage for the sake of paying off a debt or obtaining basic means of subsistence.

No doubt there is something paradoxical about the idea of forcing someone to be free. Some, following Jean-Jacques Rousseau, have tried to dissolve the paradox by suggesting that, in cases of justified paternalistic coercion (viz. cases involving the protection of a person's agency) there are really two wills being ascribed to the person being coerced: a rational will we seek to impose - the will we imagine a person would possess if she were sufficiently knowledgeable, morally reasonable, and unconstrained by abnormal mental or physical circumstances - and the self-destructive will that is actually compelling her to act against her better will, viz., in way that she could not rationally recognize or own up to. Stated thus, paternalism is justified by appeal to the voluntary consent of the one coerced on the basis of a counterfactual attribution. In that case, it ceases to be paternalism stricto sensu, if what we mean by paternalism necessarily

\footnotetext{
${ }^{1}$ By rational consent I refer to an ideal normative limit, involving both negative freedom from external and internal (psychological) constraint, as well as positive freedom, or capacity for reflection and action (autonomous agency). Discourse ethics shows that both freedom from constraint and robust agency based on a positive, secure, and integrated conception of self emerge together from within the context of communication oriented toward reaching consensus on shared norms, understandings, and loci of mutual recognition.
} 
involves countermanding the will of the coerced tout court, absent any consideration of her potential rational consent.

I will have more to say about the (perhaps unavoidably) counterfactual nature of rational consent below. Suffice it to say, I leave others to decide whether we can speak of justifiable paternalism as I have here formulated it as a form of paternalism at all and will instead focus on what I take to be a more crucial question: whether coercing others to do something for the sake of protecting or enhancing their agency is at least prima facie wrong unless doing so could be justified as acting pursuant to their consent, however formulated. It suffices to note that even paternalistic coercion aimed at preserving agency needs to be justified. For instance, it may not be right to compel people to refrain from recklessly endangering their lives by climbing steep mountains if doing so contributes significantly to their sense of well-being and defines who they. ${ }^{2}$

\section{Structural Coercion}

Paradigmatic cases of coercion are usually interpersonal, where a single person or group of persons is said to coerce another person or group. I shall argue that what is distinctive about coercion is not this kind of interpersonal relationship but social relationship generally speaking. Persons may be compelled against their will by purely natural events or accidents but they are coerced by social relationships. Such relationships can be quite impersonal; those who depend on or affect unknown others through highly mediated chains of economic exchange and environmental impact need not even be aware of their relationship. The global economy comprises a network of such relationships that now confronts us all as a seemingly autonomous force to be reckoned with in its own right, a kind of second nature whose laws of supply and demand overlay the laws of physics. Nonetheless, as Marx forcefully argued, it would be wrong to treat the impersonal relations that comprise the global economy as if they had no connection to intentional actions, as if, in other words, they were, like the laws governing nature, beyond the control of human beings.

Global economic relationships are social relations of a peculiar sort: they simultaneously emanate from and condition acts of free agency by means of a kind of feed-back loop. Because of their hybrid nature, we think of this conditioning as a relatively benign process of delimiting options for rational choice. So it seems a stretch to say that the so-called laws of capitalism as we know it are coercive at all.

Nonetheless they may be said to function so whenever they encourage forms of competition that drive down wages. The inability of small-scale, labor-intensive

\footnotetext{
${ }^{2}$ Gerald Dworkin (1983) notes that "hard" cases of paternalism - in which the rational competence of the coerced agent is not impugned by ignorance or cognitive and emotional deficiencies - are difficult to justify precisely because of the voluntary nature of the action that is suppressed. In cases such as these where the nature of the act itself (its irreversibility, as in the case of suicide, or its severe risk to the health of the actor) and not the competency of the agent is what is at issue - the coercer might justly appeal nonpaternalistically to the potential harm caused to society. For example, a society where persons are legally entitled to sell themselves into slavery voluntarily imposes unconscionable burdens on those who would be required to return run-away slaves. But perhaps voluntary acts like these can also be forbidden on "soft" paternalistic grounds, as being contrary to the "good" of the agent (here we assume something like the divided will theory noted above, in which an agent's failure to appreciate fully what is really in her best interest impugns the fully voluntary nature of her act.
} 
economies in the developing world to compete with the large-scale, high-tech economies of the developed world leads to the destruction of these economies and a corresponding loss of jobs. Within these economies, workers with jobs (especially within trades and professions) may freely choose to relocate abroad in search of better-paying jobs. But jobless workers may be left with no other alternative but to uproot themselves from their families in search of employment elsewhere - an alternative whose harm to themselves and their families can scarcely be compensated by the prospects of meager employment abroad. ${ }^{3}$

Of course, from the perspective of an economist, it may appear that their choice to migrate is just like any other value-maximizing decision, a free choice based on cold rational calculation. The emotional, physical, and monetary costs of dislocation - in comparison to the uncertain and often meager benefits they hope to gain - may indeed be counted as rationally worthwhile. I have no doubt that this may well be an accurate description of the choice faced by many migrants but the important question is: Does it do justice to the choice faced by the most desperate migrants, who have no jobs and no other viable source of income?

Although any economic system can be said to affect our fortunes adversely and in so doing be said to condition our choices in ways that compel us to make painful decisions, such a system becomes distinctly coercive when its effect on a person's life leaves that person no viable option but to act in a way that is contrary to her wishes, regardless of whether doing so inflicts great harm on her (although that too is often the choice faced by many of the world's poor migrants, who choose to uproot themselves from nation, community, and family and expose themselves to great risk, surrendering many basic rights and subjecting themselves to demeaning forms of exploitation that in the most extreme cases devolve into indentured servitude, if not slavery) (Bacon, 2008; Kaye, 2010). ${ }^{4}$

It suffices to note that the current system is not a natural fact but is a legally constituted social relationship between capitalists and workers, producers and consumers, whose structures could be altered to mitigate coercive migration. But the argument that it should be altered requires showing that the coercive nature of this social relationship as it impacts the most desperate class of migrants cannot be justified. ${ }^{5}$

\footnotetext{
${ }^{3}$ D. Schweickart (2008) argues (with Marx) that the need to maintain labor discipline and heighten profitability by lowering wage costs through labor-saving technology that is endemic to capitalism leads to chronic domestic crises of un- and underemployment (and corresponding overproduction) which are solved by opening up new markets abroad. The dumping of cheaply produced goods in developing economies and the corresponding replacement of sustainable, labor-intensive domestic agriculture with high-tech , export oriented agribusiness reinforces and exacerbates poverty and unemployment in these economies.

${ }^{4}$ Even on the rare occasions when slavery and indentured servitude are "voluntarily" contracted by "mutually consenting" parties they constitute human rights violations of the first magnitude. However, defenders of the current regime of global labor trafficking can dismiss these cases as aberrations that only exist at the margins (see note 1). In instances that fall short of indentured servitude and slavery, migrants may still be constrained by a host of factors, ranging from the threats of labor traffickers to the demands of labor subcontractors and overseers.

${ }^{5}$ Forcing developed as well as undeveloped countries to play on an even playing field established by fair trading agreements that protect vulnerable local economies from foreign competition; imposing less draconian international lending terms, refusing to deal with undemocratic governments that despoil their nation's people of their fair share of
} 
Coercive Migration as Justified Paternalism: Liberal and Communitarian Views

I have argued that the migration of at least the most desperate economic refugees - those without jobs and alternative sources of income - can be described as the outcome of a coercive social relationship. It remains to be seen whether this coercive relationship can be justified on paternalistic grounds, as advancing the good - and more precisely, the freedom or agency - of those who are coerced.

One way to answer this question is by examining two opposed conceptions of welfare and (free) agency that find their proper homes in the two opposing theoretical orientations currently dominating the immigration debate: liberalism and communitarianism. The immigration debate is often posed as a conflict between the human rights of individuals to freedom of movement, on one side, and the democratic rights of political communities to define their membership, on the other. Neither side in this debate, I contend, adequately takes into account the coercive nature of migration involving those persons whom I have designated as economic refugees.

The liberal version overlooks the coercive nature of their migration because it operates with an impoverished conception of freedom. The classical liberal view, subscribed to by many contemporary libertarians, holds that individuals have a natural or inalienable right to move freely in pursuit of their self-preservation. ${ }^{6}$ According to this view, the only coercive force that stands as an impediment to freedom is the force exercised by political communities in refusing to allow potential contractors - here represented by the domestic business owner and the foreign worker - to freely enter into voluntary wage agreements. Because market systems are seen as the foreseeable outcome of fair and free agreements between equals, market transactions that have disparate impacts on the poor appear no less consensual and just. More importantly, from this

national resources, establishing and enforcing minimum wage and collective bargaining laws, and redistributing global wealth to offset the adverse economic impact of the global economy on the world's poor are just some of the ways in which coercive migration might be alleviated. Furthermore, assigning responsibility for coercive migration however indirect that responsibility might be - is hardly meaningless. Leaders of the most powerful countries and those sectors of the business class that predominantly influence their decisions must rank as sharing the greater portion of responsibility. But citizens who elect these leaders also share partial responsibility. Indeed, once we recognize that the current economic system is not only a legal construct but is also maintained by cultural and ideological structures, it is hard not to assign some responsibility for its maintenance, however diminished, to the people who are most coerced by it. The world's poor have an obligation to enlighten themselves about the patriarchal ideologies that conduce to social hierarchies and exploitative relationships. They, too, must learn how to empower themselves into communities of resistance (Young, 2007; Ingram, 2009).

6 This is the libertarian position defended by the Cato Institute. For a contemporary philosophical defense of libertarianism, see Robert Nozick (1973). 
Lockean perspective the economy also seems non-coercive, so long as economic refugees can find jobs or other sources of subsistence through legal migration.

Against this benign view of capitalism it might be objected the unintended consequences of market transactions are hardly foreseeable, and that even if they were, they would not be the foreseeable outcomes of fair contracts. It might be reasonably asked whether all rational agents would have consented to such a system knowing how it affects the prospects of the poor.

This hypothetical question suggests an important revision in the classical social contractarian defense of the market economy. Rawlsian liberals criticize libertarians for failing to account for the coercive nature of contracts between persons possessing vastly unequal bargaining power. They argue that a voluntary agreement between, for instance, a wealthy owner of the only business in town and a starving worker who has no other job opportunity is unjustifiably coercive. They defend this claim by appeal to a hypothetical social contract, or counterfactual model of consent, of the sort Rawls himself famously deployed in A Theory of Justice (1971) and that I invoked earlier in discussing the presuppositions underlying justified paternalism. Conducted under a veil of ignorance, in which each contractor is forced to place herself in the position of everyone else, riskaversive bargainers would not consent to a system of such contracts without compensatory mechanisms of redistribution. From the perspective of the disadvantaged party (which all contractors are forced to adopt) such contracts would be deemed coercive. $^{7}$

Rawlsian liberals thus argue that non-coercive contracts must be egalitarian in at least several senses: they must be part of a legal system that does not discriminate on the basis of non-market-based considerations such as race, gender, religion, and sexual orientation; and they must guarantee equal opportunity for all to develop their capacities for agency and self-respect. This requires equal opportunity education but also compensations for those who are born with natural handicaps. Ultimately, it requires something like Rawls's difference principle, in which inequalities in the distribution of income are permitted only if they benefit the worst off.

Although Rawls himself cautions against applying his contractual reasoning to the global arena, some of his followers have done so with radical effect. They argue that, under ideal circumstances, persons should not only be free to move wherever they want to, unconstrained by political borders, but that the global economy should be arranged so as to ensure that inequalities in wealth between and within nations are permitted only if they benefit the worst off. In a famous article, Joseph Carens (1995) argues that even under the less ideal circumstances of today's world, unrestricted cross-border migration should be permitted unless doing so will endanger the liberties and rights of host communities. Here we see that, however much they might disagree with libertarians on the nature of coercive agreements, Rawlsians of realistic bent will uphold the libertarian priority of liberty over social welfare, and to the extent that they also think it important to secure the latter, they will prefer methods for doing so that favor freedom of movement over redistribution. Seen from another vantage point, however, this prioritization of liberty over welfare is misleading, since the coercive nature of capitalism as a system that structurally necessitates unemployment for some persons is not directly called into question. In other words, the economic coercion of immigrants is never ethically

\footnotetext{
${ }^{7}$ For a more detailed statement of this argument, see James Sterba (1985).
} 
challenged because it is presumed that ample compensation awaits the migrant in her new "home," which in effect amounts to redeeming the violation of liberty through provision of welfare. ${ }^{8}$ While the endangerment to a person's liberty and welfare caused by structural unemployment may sometimes be offset by migration, so that the coerced nature of relocating is redeemed, this need not be so. There is a difference between an unemployed automobile assembly line worker in a Detroit GM plant who chooses to relocate in order to find employment in a Kentucky Toyota plant and a unemployed Mexican campesino who chooses to migrate to the United States in search of any paying job whatsoever. The degrees of economic desperation each encounters as a result of being unemployed as well as the amounts of freedom, agency, and well-being each is forced to surrender in relocating are not equivalent. The American who relocates internally is typically less compelled by economic circumstances into moving (he or she can rely on unemployment benefits, welfare/workfare payments, or the surplus income provided by other extended family members). Even if he or she is required to move, and must subsequently endure the hardships associated with relocating - required, in extreme cases, to abandon family and community - the hardship is typically temporary and, most importantly, does not involve abandoning rights associated with equal citizenship. This difference in the degree of coercion and loss of rights suffered is not reflected in the Rawlsian's appeal to unrestricted migration as a solution to the problem of marketinduced joblessness. Leaving aside the foreign migrant's loss of rights (which might find legal remedy), the extreme degree of coercion suffered by some Mexican campesinos in being forced to migrate - equivalent in some respects to the extremely coercive threat of imprisonment and bodily abuse suffered by some political refugees - is less likely to be redeemed by migration, at least not to the point where we might conclude that the coercion in question is justifiable. Nevertheless, from the vantage point of Rawlsian theory, the primary threat to individual freedom (and the primary source of coercion) appears not to be the capitalist economic system, but the community of wealth that refuses to open its doors to the desperately needy.

Liberals of utilitarian bent, by contrast, defend individual freedom not as an end in itself grounded in natural law or impartial reflection on one's rational interests but as a means to promoting overall well-being for the greatest number. Classical utilitarians (classically-trained economists generally fall into this category) assume that market freedom maximizes overall wealth, which they equate with well-being. Egalitarian utilitarians, such as Peter Singer, reject this diagnosis, arguing that wealth maximization is compatible with great inequality, exploitation, and human coercion. Invoking marginal utilitarian calculations, they urge an equal redistribution of wealth as conducive to overall global well-being, in which everyone's basic capabilities will be developed.

The reference to capabilities takes us beyond what is sometimes referred to as subjective (or preference) utilitarianism and even beyond objective (or valuemaximizing) utilitarianism. For in defining well-being in terms of the realization of capabilities, it places at the forefront what Martha Nussbaum, Amartya Sen, and many have regarded as key to understanding well-being: freedom and agency. By freedom and agency they do not mean choice taken abstractly and unimpeded action (negative

\footnotetext{
${ }^{8}$ Importantly, in his later writings Rawls (2001) himself returns to his liberal roots in denying that diminution of the "fair value of liberty" as an element of democratic political action can be compensated by social welfare.
} 
freedom), but capability. The argument here is a familiar one: mere negative freedom, or freedom to choose and act without interference from others, builds upon positive freedom, or conditions that enable choice and action and that empower agency. These conditions include certain kinds of primary goods, such as nourishing sustenance, health, education, and self-recognition of one's status as an individual agent as well as opportunities for gainful employment and political participation. Such goods as these, however, are not immediately translatable into conditions of agency unless they are used to cultivate conditions that are: to wit, physical, psychological, affective, and cognitive capabilities. That the cultivation of these kinds of capabilities depends on entering into social relationships with others goes without saying. However, what often gets overlooked in this simple equation is the importance of belonging to a community of mutual recognition in which others deeply care about us and in so doing nurture within us a sense of self-confidence, self-respect, and self-esteem (Honneth, 1996).

Here we see how the liberal prioritization of individual freedom passes over into the communitarian prioritization of egalitarian solidarity. Robust freedom depends, first of all, on intact familial relations based on love. The self-confidence requisite for taking initiative and resisting the coercive aggression of others involves internalizing the positive, self-assertive image of a primary caretaker with whom we identify emotionally (viz., someone who loves us and whom we love in return). Robust freedom also depends on legally constituted civil associations based on citizenship, or political membership. The self-respect requisite for entering into voluntary, cooperative ventures with other members of the community must be guaranteed by equal property rights as well as equal civil rights to associate, speak freely, and pursue one's conception of the good; ultimately it must be guaranteed by political rights bestowing an equal opportunity on everyone to influence the making of laws that define the legal limits of one's freedom.

Finally, robust freedom depends on social relations bound together by mutual feelings of solidarity. One's sense of social agency can be damaged by being made to feel inferior or subaltern, by being forced to take on an unfair share of society's burdens and sacrifices. Persons who are maintained in a state of poverty or welfare dependency, who are consigned to demeaning and dehumanizing forms of labor with little control over their workplaces, who are treated as mere objects or means for others' selfaggrandizement, or who are shunned because of their race, religion, gender, ethnicity, disability, or sexual orientation, are denied the recognition so essential to cultivating a sense of self-esteem. Needless to say, severe absence of self-esteem and/or misrecognition define(s) the condition of many migrant workers, regardless of whether or not they are legally documented. They may feel a sense of self-esteem for sending vital remittances to their families back home but still suffer from societal discrimination based on their appearance and 'alien' origins. The degree of misrecognition is magnified even further for those who are legally undocumented; for they are additionally threatened with deportation (which for some means removal from family and community). This extreme degree of powerlessness afflicts many undocumented migrants, including those who perhaps come from middle class backgrounds and earn good wages in their host country. However, it is a condition that especially plagues economic refugees, who often lack the education and resources requisite for acquiring legal work permits (which, in the case of the United States, are overwhelmingly reserved for persons who are sponsored by family 
members already residing in the country or who possess special technical skills associated with middle class education).

In sum, for the communitarian, it is not the community that poses the greatest threat to freedom but the abstract individual and his negative freedom. Coercive are social relations that engender self-centered forgetfulness of the ontological priority of community. These are social relations that engender social conflict, promote social inequality, corrode a sense of social solidarity, and inhibit the conditions of mutual caring and mutual identification so essential to developing a robust sense of one's agency (Walzer, 1990). From the perspective of the communitarian, because the sorts of contractual relations between employer and employee, seller and buyer definitive of a capitalist economy are structured as a strategic contest between opposed wills, they invariably give rise to social relationships in which antagonistic parties coerce, or threaten to coerce, one another. In the end, the powerful succeed in imposing their will on those too powerless to resist. If they do resist, then both parties acquiesce in a mutually coercive compromise whose function is to secure a temporary truce up until the balance of power shifts. So high are the stakes in this war that all aspects of political life are influenced by it. The business class seeks to increase its own share of the public wealth at the expense of the working class, even if this means downsizing safety nets and other social guarantees that provide a semblance of equal opportunity. In the final analysis, the power of global capital exceeds that of governments to such an extent that multinationals and international banks can simply dictate whatever terms they want to local communities.

But it is not only capital that threatens the self-determination of the community; threatening, too, is the displaced foreign worker who insinuates herself into a solidaristic association as a competitor for scarce resources. The individual freedom to contract thus stands opposed to the community's freedom to determine the conditions and membership of its own exclusive association (Walzer, 1983).

To recapitulate: because liberals and communitarians propose conflicting conceptions of freedom they assess the coercive nature of global capitalism differently. Liberals of libertarian bent generally do not find capitalism coercive, since they believe that a universal system of unregulated market transactions based on unlimited freedom of contract would reach a state of equilibrium in which no one would feel coerced into giving up something good for something worse. Many of them might well conclude that today's desperately poor migrants are not being coerced into abandoning their families and communities, since by moving abroad they are simply choosing to optimize their overall utility. Others, however, might concede that the current starting positions of rich and poor are unjust, having arisen from a past history of colonial injustice, or they might concede that the current rules of 'unfree' trade and finance unfairly permit the powerful to impose their will on the less powerful. These libertarians might therefore concede that current contractual relationships between rich and poor are coercive and unjust.

Rawlsian liberals, too, will assess the coercive nature of global capitalism differently, depending on whether they think it comports with the liberty and difference principles, or at the very least the minimal conditions requisite for engendering and maintaining what Rawls in The Law of Peoples (1999) calls a "well-ordered "people" or self-sustaining political community. Rawls tells us that in an ideally just world of wellordered peoples, people would feel no need to migrate for political or economic reasons, 
since they would be satisfied with their lot in life, unequal though it might be in comparison to the affluent lifestyle of people living in other countries. Until that time is reached, well-ordered peoples have a duty to assist "burdened societies" in achieving the material and cultural conditions requisite for political stability and economic sustainability.

Rawls mentions the importance of fair trade agreements in sustaining a just world order, yet he seems otherwise oblivious to the coercive nature of global capitalism. Some of his students, however, have argued that the current system of global trade and finance must be condemned as coercive and harmful according to the difference principle, since ever more people die from poverty-related causes under what has become the most unequal distribution of global wealth that has ever existed (Pogge, 2002). These considerations have led Carens to propose a relatively open immigration policy - a global redistribution of people, as it were - as an alternative to a global redistribution of wealth. However, this response seems to uphold the innocence of a capitalist system that coerces migration. Such coercion is justified as beneficial insofar as the lack of sustainable employment imposed on the would-be migrant's local economy is alleged to be more than compensated for by the growth of better paying jobs in the migrant's host economy.

Although libertarian and Rawlsian liberals believe they can deny or justify the coercive impact of the global economic system on the most desperate economic refugees, this presumption is hard to maintain on the basis of the facts. The coerced migration of economic refugees cannot be redeemed by compensating them with prospects of employment. Even if we assume that the migrant's employment prospects are significantly better in his(her) host country than any he(she) could have hoped to find in his(her) home country, and even if we further assumed an 'open borders' immigration policy that endowed him(her) with equal citizenship rights, we would be no more entitled to claim that an economic system that forced him(her) to relocate was justified on paternalistic grounds than we would be to claim that a political system that forced him(her) to relocate was justified because it gave him(her) an opportunity to live under a freer regime. Certainly, from the refugee's point of view, neither system that coerced him(her) into relocating where circumstances eventually proved to be maximally favorable for him(her) would be considered legitimate and justifiable.

Unlike classical utilitarian liberals, for whom overall wealth maximization is the single important moral value, egalitarian utilitarian liberals will respond to the economic coercion of the poor as a matter of concern, in much the same way that Rawlsian liberals do. They will accept the justice of such coercion only to the extent that it is redeemed through compensatory redistributive policies that improve the economic well-being of the worst off. To the extent that they prioritize the primary good of negative liberty over other primary goods constitutive of welfare, they too will favor the redistribution of people (facilitated by open labor markets) over the redistribution of wealth. Only if they prioritize the primary good of positive freedom - and community - will they think otherwise.

Unlike her liberal counterparts, the communitarian has a deeper grasp of the coercive nature of global capitalism. In her opinion, the undermining of agency, or positive freedom, cannot be compensated for by allowing a negative freedom to migrate, even if this promises greater material prosperity through remittances and the like. Instead, the communitarian will assess the coercive nature of global capitalism from the 
perspective of her own community - and not from the perspective of those outside it. That is to say, she will appreciate the full extent to which global capitalism threatens the freedom of her fellow citizens; but lacking solidarity with foreigners, she will underappreciate the extent to which it threatens their freedom. Hence, in the face of migratory pressures caused by global capitalism (and its relatively irremediable consequences, drought and flooding caused by energy-induced global climate change), she will act to restrict the freedom of the would-be migrant for the sake of preserving the cultural, political, and economic integrity of her own compatriots.

This dichotomy in the moral assessment of harm and our proper response to it follows from the communitarian privileging of relations involving members of her own community over relations involving her community and outsiders. We owe the strongest duties of protection and aid to members of our own community, people with whom we are bound by deep social ties and solidarity. Duties to forbear from harming (or to prevent the harming) of foreigners may also be regarded as equally strong by the communitarian, if she and her compatriots imagine that the protection of human rights is an important part of their liberal communitarian ethos; but the positive duty to assist foreigners in distress, universal though it might be, will be relatively weak in comparison to the duty to protect the community.

This communitarian privileging of the insider's perspective for assessing coercion, harm, and remedy depends, of course, on maintaining a solid distinction between insider and outsider. In particular, it depends on delimiting a sharp boundary around the community and its internal relations in a manner that effectively isolates the community from the rest of the world. In an age of globalization, the distinction between "us" and "them," between social relations among insiders who recognize each other with a sense of common purpose and identity and social relations among strangers who regard each other as outsiders becomes increasingly problematic. As Iris Young notes, our "social connectedness" with foreigners through economic dependency obligates us to remedy structural injustices that are implicated in this dependency. Our duties in this regard may be on a par with our strong duties to fellow citizens as well as with our strong duties to respect (and protect) the human rights, generally. At the very least, duties of social connectedness are (arguably) stronger than duties to aid distressed others with whom we are not connected. Pursuant to this suggestion, I will now propose that the theoretical orientation best suited to showing that the duty to prevent harms in which we are directly or indirectly implicated through social connection is neither liberal nor communitarian but discourse ethical.

\section{Discourse Ethics and the Assessment of Coercion}

We have seen that neither a liberal nor a communitarian approach permits a full appreciation of the coercive nature of global capitalism and therefore neither enables us to fully understand why this coercive structure cannot be redeemed on paternalistic grounds. For liberals, if global capitalism is coercive, it is not unjustly coercive. In their interpretation, coercive migration can be justified as promoting the short- or long-term freedom and well-being of migrants, so long as wealthy political communities do their part by eliminating restrictive immigration barriers. In the short term, open immigration policies might not be justified as mutually beneficial to everyone, as domestic workers 
lose jobs to desperate migrants willing to work for less and as poor communities lose their workforce to wealthier ones. However, the coercive nature of these unequal shortterm effects can still be justified in the long term, as being mutually beneficial from the counterfactual vantage point of an ideal rational spectator, who represents the interests of future as well as of present generations. To communitarians, by contrast, coercive immigration cannot be justified because it constrains the community, not the would-be migrant. So long as the coercive effects of capitalism are mitigated by domestic welfare policies, on one side, and protectionist trade and immigration policies, on the other, it too can be redeemed. Yet because migrants confront the members of our community as outsiders with whom we have no special obligations, their feelings of being coerced will find no place in our moral deliberations.

I submit that we need an alternative theoretical approach that recognizes both the economic refugee's and the community's distinct experiences of coercion. The most promising approach, I believe, is discourse ethics. According to discourse ethics, a coercive norm is legitimate if and only if all persons who are affected by it could consent to it as satisfying their common interests, but only after having rationally deliberated together. ${ }^{9}$

Superficially, this procedure for moral deliberation resembles the kind of hypothetical, social contractarian thought experiment proposed by Rawlsian liberals. In the form of ideal theory, both the ideal speech situation and the original position stipulate that hypothetical discussants remain free from external constraints and internal prejudices; both position these contractors as equals; both ensure impartiality; and both require universal consent as a condition for non-coercive social cooperation. At this level, the difference between them resides in how they model consent: as an already existing agreement of interests that is revealed by abstracting from real differences or as an agreement brought about through dialogically transforming interests in mutual questioning wherein each must empathetically identify with the other.

Discourse ethics invokes consensus as a dynamic outcome of shared reflection and criticism; as each must recognize the potential validity of others' interests, values, and social perspectives in persuading them to recognize the validity of his or her own, each must also qualify and transform these very same interests, values, and social perspectives. Willingness to reflect together, free from the external constraints of action, leads to the overcoming of internal constraints (prejudices and partial perspectives). The expansion and fusion of horizons in turn makes possible undistorted relations of mutual recognition that enhance capacities for reflection, choice, and action. At the same time, the pre-requisites for entering into genuinely identity-risking dialog are given only when each has sufficiently developed minimum capabilities of speech, reflection, empathy, and authentic self-expression and self-understanding.

The emphasis on mutually transformative critique that distinguishes discourse ethics from Rawlsian social contract theory at the level of ideal theory becomes clearer at the level of non-ideal theory. As the veil of ignorance is lifted in real processes of legislative and judicial deliberation, principles that have been settled upon ideally must

\footnotetext{
${ }^{9}$ Obviously, differences in how an agreement affects third parties must be taken into consideration. My former girlfriend shouldn't need my consent in choosing to marry my enemy - as much as it might adversely affect me. Agreements that affect the exercise of others' human rights - or their agency - are a different matter.
} 
now be tailored to the constraints of reality. Discourse ethics, by contrast, begins with concrete conflicts embedded in real life; it demands real - not hypothetical - dialogue as a prerequisite for impartial deliberation at all levels of reasoning. In genuine dialog, all relevant perspectives have an equal opportunity to be voiced and all claims have an equal chance to be defended and criticized, under the guiding expectation that only the best argument will compel agreement.

There is a difference between imagining oneself to be any other person and imaging oneself to be this singular person standing before me now. In the former case, my interests remain entirely abstract, disassociated from the concrete community to which I belong. As a reasonable citizen of any liberal democracy, my interests compel me to prefer a scheme of justice in which each person's negative liberty is maximized, each person is respected and has basic civil, political, and property rights, and no overall improvement in economic well-being is permitted unless it benefits the worst off. Abstractly considered, I value my individual freedom above any gains in material prosperity I might be offered in exchange for it.

Applied to the global arena, the Rawlsian method of ideal role taking, facilitated by the hypothetical self-imposition of a veil of ignorance, allows me to imagine myself being one of the world's worst off, say (for instance) a poor, unemployed Mexican farmer. Although a plausible interpretation of a global difference principle might require something like a Marshall Plan for building up the Mexican economy, it might more plausibly be interpreted, given the priority of the liberty principle, as allowing the Mexican farmer to migrate without impediment. On neither interpretation are we required to consider the coercive nature of global capitalism; our response to the injustice befalling the Mexican farmer is a response to a violation of the difference principle taken abstractly, not a response to his description of his own situation as the outcome of being coerced (unjustifiably) by economic structures. If we assume that the difference principle is best satisfied by permitting unrestricted migration, both the migrating campesino and the host community's respective understanding of how the structures of global capitalism have coerced them will remain unspoken for.

By contrast, from a discourse ethical perspective, both the campesino's and the community's respective interpretations of the coerciveness of economically induced migration will be given full expression. In trying to reach agreement on a fair immigration (or compensatory economic) policy, the coercion described by both sides becomes a matter of discussion, in light of which our sense of collective responsibility becomes clarified. The virtual representation of arguments taken in the abstract dissociated from the autobiographies of their advocates - fails to do justice to their rhetorical cogency. For this reason, discourse ethics requires the descriptive representation of affected groups by members of those very same groups, who can speak to the coercive effects of institutions and double-bind situations from the standpoint of their own lived experience.

To be sure, the sense of collective responsibility will be shaped, in part, by abstract considerations pertaining to economic theory. It will also be shaped by our understanding of history. When considering the historical relationship between the United States and Mexico, for instance, the protectionist narrative proffered by communitarians in the United States who are concerned about limited jobs and resources (and 'national identity') will have to incorporate the counter-narrative of imperial 
expansionism, inequitable trade relations, coercion, and victimization narrated by Mexican and Central American migrants. Finally, our sense of collective responsibility will be informed by a personal sense of connectedness with the other, deepened by listening to the other's personal life story.

As a method of moral deliberation, discourse ethics does not propose a simple solution to the problem of coercion. Perhaps, as Seyla Benhabib (2003) has argued, it would prohibit communitarian immigration policies that impose qualifications based on race, ethnicity, gender, religion, sexual orientation, and other "ascriptive" properties, because such policies could not be rationally justified to all affected. One wonders whether this stricture might not be extended to other qualifications that she finds unobjectionable, such as language competence, education, capital assets, and possession of marketable skills. Benhabib also believes that discourse ethics would ground the full spectrum of human rights, once we see that respect for the individual is embedded in any genuine dialog. So construed, the rights of economic refugees facing immanent danger would have a special claim on us. That said, arguing from the communitarian side, she observes that preferences based on nationality, kinship, and the like may be justifiable so long as they do not exclude others and do not trump the rights of refugees.

Whether or not one agrees with Benhabib, it is clear that she confines her application of discourse ethics to the big questions concerning the relationship between human rights (a traditionally liberal concern) and participatory democracy (a traditionally communitarian, or civic-republican, concern). Her focus is therefore predominantly legal and political. She quite rightly notes that from a discourse ethical perspective individual rights and democracy are complementary. The content of our rights - including human rights - must itself be the outcome of collective legislation informed by fair democratic procedure; and the content of democratic procedure, in turn, must be the outcome of collective legislation shaped by rights and informed by public opinion. The circular relationship between rights and democracy - what she, following Jacques Derrida, calls 'democratic reiteration' - illustrates the importance of communitarian solidarity for liberal freedom and vice versa. ${ }^{10}$

Given discourse ethics' correspondingly enriched conception of agency and freedom as an outcome of discursively achieved mutual recognition under unconstrained and egalitarian conditions of shared deliberation and reflection, it possesses a unique capacity to gauge the dialectic between communal self-determination and individual freedom that informs the immigration debate. Because communication is global, and community is cross-border, political boundaries are becoming increasingly porous, accommodating "disaggregated" forms of membership. Within the context of a multicultural society, the communal solidarity so essential for the formation of free agency must be conceived weakly in terms of what Jürgen Habermas calls 'patriotic constitutionalism,' or loyalty to principles of toleration, rights, democracy, and the rule of law. So construed, one can no longer argue, as communitarians do, that the migratory

\footnotetext{
${ }^{10}$ Discourse ethicists like Benhabib tend to focus on policy debates and general norms of justice. But the justification of any norm cannot be separated from its application to concrete individuals. We may have at our disposal a number of norms that strike us as prima facie just but whose complete validation depends on being appropriately qualified with respect to a range of situations. In applying the most appropriate norm to a given situation, we must describe that situation from the standpoint of all those concerned, a process that involves reaching agreement on an interpretation that does justice to everyone's perspective (Ingram, 2009).
} 
patterns unleashed by global capitalism are coercive because they undermine the 'thick' cultural identity of traditionally ethnic, racial, and religious communities. In contexts of multicultural discourse, the identity of the insider is inextricably linked to - and altered by - the identity of the outsider.

\section{Concluding Remarks}

Discourse ethics requires that we obtain the consent of others to coercive arrangements only after we and they have rationally agreed that these arrangements are in all of our best interests, and that means only after we and they have transformed our conflicting interests in light of mutually understanding our diversely situated needs, as narrated by our concrete life histories. Because discursive rationality is itself tied to capabilities of unconstrained mutual recognition that continually develop within discourse itself, it designates a counterfactual ideal whose conditions for realization also continually evolve and are at any moment only more or less approximated sufficient to warrant our faith in whatever agreement (or disagreement) follows therein. Because chances for reaching consensus on controversial policies even under the best of circumstances are slim, what matters most is the process of increasing mutual understanding and fusing interpretative standpoints by which we can formulate more comprehensive descriptions of our economic relationships. Listening to the stories of migrants who have been forced by economic necessity to uproot themselves from family and community - and listening to the stories of those whom they have left behind as they confront their own diminished capabilities - cannot but convince those of us who live in affluent communities of the truly terrible choices these migrants and their families must make, choices that they ascribe to economic necessities that they do not recognize as justifiable, however much such necessities might occasion new opportunities for long-term betterment. ${ }^{11}$ In light of these narratives, it becomes impossible to defend on paternalistic grounds the forced migrations of economic refugees set in motion by global capitalism. Doing justice to economic refugees therefore requires taking their perspective into account when deliberating on immigration policy. Appreciating the coercive impact of global capitalism on them will therefore require altering our practices of moral reasoning so as to incorporate their narratives of freedom lost into a much larger call for decriminalizing undocumented aliens, conferring amnesty on those who have met reasonable residency requirements, and mitigating the violence of a global economic order that has forced their migration in the first place (Ingram, 2009).

\footnotetext{
${ }^{11}$ Space limitations prevent me from elaborating more on the advantages of discourse ethics in assessing the coercive impact of global capitalism on migrants. However, the demand that we empathetically respond to the concrete needs of individuals and not just to the general needs of representative groups suggests that discourse ethics shares a great deal in common with the contextual, relational ethics associated with a narrative-based care ethic. This advantage, which makes discourse ethics especially suitable for addressing the issue of coercion in the debate over immigration, is often underestimated even by those, such as Seyla Benhabib, who have made a point about this advantage in other contexts.
} 


\section{References}

Bacon, D. (2008). Illegal people: How globalization creates immigration and criminalizes immigrants. Boston: Beacon Press.

Benhabib, S. (2003) The rights of others. Cambridge: Cambridge University Press.

Carens, J. (1995). Aliens and citizens. The rights of minority cultures, ed. W. Kymlicka. Oxford: Oxford University, 331-45.

Dworkin, G. (1983). Paternalism: Some second thoughts.. Paternalism, ed. R. Sartorius. Minneapolis, University of Minnesota.

Honneth, A. The struggle for recognition: The moral grammar of social conflicts. Cambridge, MA: MIT Press.

Ingram, D. Immigration and social justice. Peace Studies Review, 14/4, 403-414.

Ingram, D. Of sweatshops and subsistence: Habermas on human rights. Ethics and Global Politics, 2/3, 193-217.

Ingram, D. (2009). Exceptional justice? A discourse-ethical contribution to the immigrant question. Critical Horizons 10/1, 1-30.

Kaye, J. (2010). Moving millions: How coyote capitalism fuels global Nimmigration Hobokin, N.J.: Wiley \& Sons.

Nozick, N. (1973). Anarchy, state, and utopia. New York. Basic Books.

Pogge, T. (2002). World poverty and human rights: Cosmopolitan responsibilities and reforms. Cambridge: Polity Press.

Rawls, J. (2001). Justice as fairness: A restatement. Cambridge: Cambridge University.

Schweickart, D. (2008). Global poverty: Alternative perspectives on what we should do - and why. Journal of Social Philosophy, 39/4, 471-91.

Sterba, J. (1985). From liberty to welfare. Social Theory and Practice ,11/3, 285-305.

Walzer, M. (1983). Spheres of justice: A defense of pluralism and equality. New York: Basic Books.

Walzer, M. (1990). The communitarian critique of liberalism. Political Theory, 18/1, 623.

Young, I. M. (2007). Responsibility, social connectedness, and global labor justice. Global Challenges: war, self-Determination, and responsibility for justice. Cambridge; Polity Press, 159-86; 